\title{
Trends in Gender Equality in the UK, 1968 to 2012: Four Barriers to 'Equal Pay' for Women
}

\author{
Jacob Tattam ${ }^{1} \&$ John Simister ${ }^{1}$ \\ ${ }^{1}$ Manchester Metropolitan University, United Kingdom \\ Correspondence: John Simister, Manchester Metropolitan University, United Kingdom \\ Received: August 31, 2014 \\ Accepted: September 23, 2014 \\ Available online: October 27, 2014 \\ doi:10.11114/aef.v1i2.504 \\ URL: http://dx.doi.org/10.11114/aef.v1i2.504
}

\begin{abstract}
This paper disaggregates the pay gap between men and women into four possible 'barriers': access to paid work; part-time versus full-time jobs; entrance into higher-paid jobs; and similar pay for equivalent work. UK data from 1968 to 2012 are analyzed, to investigate these possible barriers. All four barriers have persisted for decades, and all four 'barriers' tend to work in favour of men. There is evidence of progress in gender equality since 1968 - for example, the 1970 'Equal Pay Act' and 1975 'Sex Discrimination Act' seem to have reduced inequality; but some forms of discrimination seem immune to attempted equality legislation and change.
\end{abstract}

Keywords: gender equality; equal pay; discrimination; labour force.

JEL classification: J71; B54.

\section{Introduction}

Many social scientists advocate 'meritocracy', in which the best candidate for any vacancy should be chosen. For example, excellence in performing brain surgery is a rare skill; prejudice against employing women as surgeons would deny the best possible treatment to patients. Excluding women from jobs such as cabinet minister would impair political decision-making. Hausmann (2012: 2) wrote 'The most important determinant of a country's competitiveness is its human talent - the skills, education and productivity of its workforce - and women account for one half of the potential talent base throughout the world. Closing gender gaps is thus not only a matter of human right and equity; it is also one of efficiency'.

Neoclassical economics suggests competition drives out prejudice, because any firm prejudiced against women cannot compete with meritocratic firms. However, empirical evidence suggests considerable inequality between UK men and women, regarding equal pay. There are different types of inequality: for example, 'glass ceilings' impede female promotion; and women may receive lower wage-rates than men in identical jobs.

There are many relevant factors regarding gender differences in labour markets. For example, one view is that "The main reasons for the gender pay gap are differences in men's and women's work experience and education; institutional causes of wage differentials, e.g. firm size or union membership; cultural expectations about women's pay; and underlying structural factors" (UK government, 2010: 2). The wide range of barriers to equal pay and there causes shows an amalgamation of various legislation and solutions are needed to overcome the damage of discrimination, unequal opportunities and cultural socialization. This paper disaggregates gender pay gaps into four possible 'barriers' to equality: a woman's ability to get a paid job; women trapped in part-time work; female access to well-paid occupations; and equal pay for equal work.

\section{Literature review}

Economists have tried to explain gender inequality in labour markets. A dominant view is neoclassical economics, which claims productivity - rather than discrimination - causes gender labour market differentials. This builds on perfect competition: a profit maximising firm is assumed to pay each employee the value of their work - if some workers are paid less, it can be argued to be due to lower productivity. Neoclassical economists claim competition corrects market failures: a firm which never hired women has a smaller pool of labour from which it employs, whereas non-discriminating firms access more human capital - reducing their labour cost; non-discriminating firms undercut discriminating firms' prices, driving them out of the market. This suggests capitalism brings a fair outcome for women. In the Forbes list of the ten best-paid chefs, eight are men (Pomerantz, 2012); from this evidence, neoclassical 
economics suggests men are better than women at cooking - but is this viewpoint reliable?

Wage differentials between genders may, or may not, be due to productivity differences as it is very hard to dissect the data (Blau \& Simpson, 1998). Gary Becker's taste-for-prejudice model assumes some employers are 'prejudiced' holding preferences with no rational reason (Woolley, 1998: 314). If a firm pays some workers lower wages than others, it may increase profitability (Becker, 1971: 14). Seguino (2000) found that in a semi-industrialised export-driven economy, gender inequality could signal increased profitability in that country, due to lower female wages; this could increase investment in that country.

Neoclassical economic analysis of labour markets includes Human Capital Theory, which suggests education increases productivity: but England (1982) argues that human capital theory only explains inequality if labour is paid according to marginal productivity. In previous generations, women tended to leave education earlier than men - Bandiera \& Natraj (2013) suggest this partly explains lower female employment. Educational levels of men and women are now similar in UK; but today's labour force includes employees of various ages - older women tended to have fewer education opportunities than men of the same age. Even now, women tend to study different subjects to men (for example, women are less likely than men to study science \& engineering); if subjects studied by women are less desirable to employers, education or the socialisation behind female educational choices may explain some of the gender pay gap.

'Segmented labour market' theory was created by institutional economists unhappy with other approaches (such as neoclassical economics): it focuses on institutions creating barriers, producing different segments such as high-wage (male) and low-wage (female) employment. Within segmented labour market theory, 'dual labour markets' is the gap between primary \& secondary markets: the primary market featuring high wages, secure jobs, and steady employment; whereas the secondary market shows job insecurity, lower wages, and volatile employment. Segregation is a result of evolving product markets and competition: high wages of primary workers cannot be explained simply in terms of higher labour quality. Most secondary workers could perform well in primary jobs, but rationing access to good jobs denies them opportunities (McNabb \& Ryan, 1990: 4).

Institutional economists don't accept that competition will correct gender discrimination: social and economic forces cause inequality to become embedded in institutions and markets around the world (Anker, 1998; Branisa et al., 2013), causing labour market discrimination due to artificial barriers, such as vertical and horizontal segregation. Discrimination outside labour markets may result from media affecting attitudes. Polacheck (1974) claimed women feel less penalised for career breaks in predominantly female occupations and part-time roles. As fewer women prioritise having a family, this could cause more females in full-time employment, and women joining predominantly male occupations. Society distinguishes between paid and unpaid work, segregating sexes (Townshend, 1989: 1). Female working hours outside of paid work are not taken into consideration however they are often expected to manage the household and therefore limit their earning potential working hours.

Some previous research studied wage-rates: for example, Corbett \& Hill (2012) use regression to analyse wage-rates of full-time graduate employees. But gaps in hourly wage-rates are not the only gender difference; men $\&$ women often have different jobs (horizontal occupational segregation), making pay gaps hard to measure. 'Skill' is subjective and difficult to measure; in a profession such as a fire-fighter, people may assume the job requires a high level of physical strength - and that men usually perform better at this. Some women now perform jobs previously seen as exclusively male; technological advances are reducing the importance of physical strength (Alesina, 2010).

It is difficult to assess the extent of wage discrimination, because there are many influences on a woman's earnings such as whether she lives in an inner-city (Hirsch, König \& Möller, 2013). Samuelson \& Nordhaus (2005: 259) wrote about the USA "The largest group to suffer from economic discrimination is women. A generation ago, women earned about 70 percent of the wages of men. Part of this was due to differences in education, job experience, and other factors. What lay behind the income differentials between men and women? The causes are complex, grounded in social customs and expectations, statistical discrimination, and economic factors such as education and work experience".

Some occupations are male-dominated: "Women tend to be overrepresented in lower paying occupations and underrepresented in higher paid ones" (Ehrenberg \& Smith, 2000: 418). It is not clear if this is due to market forces, or forces outside the economy. Females may be pushed towards certain careers from an early age; childhood socialisation (such as parents expecting girls to play with dolls, and boys to play with cars) may encourage women to become teachers or nurses. Mincer \& Polacheck (1974) suggested women choose predominantly female occupations, as they would be penalised less for time outside the labour market raising children in mainly female occupations, than in mainly male occupations.

Due to government regulations, women are allowed maternity leave (depending on how long they worked for their employer); firms may avoid employing women to prevent this risk. Hence if fewer women than men are employed, this may be due to discrimination by employers. This is associated with 'statistical discrimination'. When companies cut 
labour costs, part-time workers tend to be the first to be made redundant; this can disproportionately affect women's employment.

Another form of discrimination is vertical segregation in the labour market, often called "glass ceilings": it is the lack of promotion to higher-paid roles for women (Guy \& Newman, 2004). Pay differentials in identical jobs are related to vertical and horizontal segregation: women may be overqualified, but unable to gain promotion due to industrial barriers. USA has low occupational segregation and productivity gaps between men and women relative to other countries; however, female earnings as a ratio of males is 0.67 - ranking USA in the middle of the global table, with Sweden top at 0.77 (Ehrenberg \& Smith, 2000: 423). Some firms may believe training for higher positions should be spent on men, because men are less likely to have a career break for children. In a survey of 3000 'Institute of Leadership and Management' members, $73 \%$ of female respondents felt there are barriers for women to higher managerial roles (Vinnicomb \& Doldor, 2014). Among FTSE 100 firms, there are only two female CEOs (Burberry, and Imperial Tobacco Group Ltd). In 2011 Lord Davies set a target for FTSE 100 company boards members to be 25\% female the number has risen from $12.5 \%$ to $20.7 \%$ in 2014 (Vinnicombe et al., 2014). As of writing the number is now 48 off the target, however if the target is not reached then the government has promised it will create legislation similar to Norway (where any listed company must have $40 \%$ of each gender on their board). Samuelson \& Nordhaus (2005: 259) wrote "until recently, few women were elected to the boards of directors of large corporations, to senior partnerships in major law firms, or to tenured professorships in top universities".

The 'Equal Pay Act 1970' came into force in 1975, to create gender equality: women in the same job as men are now entitled to the same pay, holiday, pensions, and bonuses; although a big step in reducing labour market discrimination, it has limitations. Due to the 'Sex Discrimination Act 1975', women can sue if they face unfairness in promotion. In the case of Schofield versus Double Two Ltd, the firm employed two trainee supervisors, a male and a female. After some time, the male trainee was offered the role of assistant manager, but the post wasn't offered to the female trainee - she had no way to apply for the job, and didn't know of its existence until her colleague was promoted. Her claim for sexual discrimination was successful (Clarke, 1994). Reducing gender disparities is paramount for social harmony and efficiency in the household and economy (Pahl, 1990); new legislation might break down barriers and discrimination (Chiplin \& Sloane, 1974).

Gunderson (2006: 3) claimed "The most common procedure for ascertaining the portion of the wage gap that can be attributable to discrimination is the Blinder-Oaxaca decomposition", assessing wages to see if a woman is paid less than a man with the same skill level (Gunderson, 2006: 4); for example, Harkness (1996: 26) estimated influences on male wages:

$$
\log \left(\mathrm{W}_{\mathrm{m}}\right)=\mathrm{b}_{\mathrm{m}} \mathrm{X}_{\mathrm{m}}
$$

Similarly for female wages:

$$
\log \left(\mathrm{W}_{\mathrm{f}}\right)=\mathrm{b}_{\mathrm{f}} \mathrm{X}_{\mathrm{f}}
$$

Hence

$$
\log \left(\mathrm{W}_{\mathrm{m}}\right)-\log \left(\mathrm{W}_{\mathrm{f}}\right)=\mathrm{b}_{\mathrm{f}}\left(\mathrm{X}_{\mathrm{m}}-\mathrm{X}_{\mathrm{f}}\right)+\left(\mathrm{b}_{\mathrm{m}}-\mathrm{b}_{\mathrm{f}}\right) \mathrm{X}_{\mathrm{m}}
$$

W represents wage-rate, $\mathrm{X}$ is characteristics such as work experience; subscripts $\mathrm{m}$ and $\mathrm{f}$ represent male and female; coefficients $b_{m}$ and $b_{f}$ are estimated by regression. This Blinder-Oaxaca decomposition divides a pay differential into two parts: the part 'explained' by group differences in productivity, such as education or work experience; and a residual not explained by productivity differences (Jann, 2008: 453), shown above by $\left(b_{m}-b_{f}\right)$ in equation (3).

Focusing on hourly wage-rates may neglect discrimination preventing woman entering paid work, or keeping women in part-time jobs. In UK, the pay gap between full-time men's and women's median earnings was estimated by UK government (2010) as $10.5 \%$; the overall gap, comparing pay of all men \& women in work, was much larger at $20.2 \%$. Harkness (1996: 4) reported that full-time employed women tended to catch up with male wages, since the 1970s; but among part-time employed women, narrowing of the pay gap in the mid-1970s (associated with the 'Equal Pay Act' and 'Sex Discrimination Act') was followed by a widening of the pay gap up to at least 1993. In 1997, around $45 \%$ of women in the UK labour market worked part-time; women working part-time earned only $58 \%$ of male full-time workers pay rates (Patterson, 1997). 


\section{Data and Methods}

Most data for this paper are from the 'Family Expenditure Survey' (FES), a large nationally-representative survey based on a sample of households by the UK government. FES surveys were replaced by similar surveys: 'Expenditure and Food Survey' from 2001, and 'Living Costs and Food Survey' from 2008. In this paper, these surveys all referred to as FES. Each FES survey investigated about 7,000 households. Data from FES, EFS, and LCF are made available by the UK Data Archive. Any errors in data analysis are the responsibility of the authors, not the UK government or Data Archive. For this paper, data on adult members aged 16 to 59 are analyzed (including 'proxy' responses, where a household member reports data on other persons in their household); self-employed people, and people still in full-time education, are excluded. Earnings are converted to 2012 prices, using price index CDKO (UK government, 2013).

This paper uses a different decomposition to Blinder-Oaxaca: here, the gender pay gap is disaggregated into four possible barriers to gender equality:

* Barrier 1: are women as likely as men to be employed?

* Barrier 2: among employed people, do women tend to do fewer hours than men?

* Barrier 3: are women less likely than men to be in relatively highly-paid jobs?

* Barrier 4: among a particular type of job, are men paid a higher wage-rate (on average) than women?

This 'four barriers' approach is summarised in equation (4).

$$
\mathrm{PAY}_{\mathrm{i}}=\left(\mathrm{P}_{\mathrm{i}}\right)\left(\mathrm{H}_{\mathrm{i}}\right)\left(\mathrm{M}_{\mathrm{i}}\right)\left(\mathrm{W}_{\mathrm{i}}\right)
$$

In equation (4), $P_{i}$ is the probability of person $i$ having a paid job; $H_{i}$ the average number of paid hours (per year); $M_{i}$ the probability of being in a highly-paid (managerial) job; and $\mathrm{W}_{\mathrm{i}}$ the wage-rate among people in a 'highly-paid' job. This paper ignores unearned income (e.g. interest on savings). In this paper, managers are treated as a separate category - controlling (to some extent) for the effects of skill, assuming skill differences between two managers tends to be smaller than the skill differences between two musicians, for example. Chart 6 uses industry codes, simplified by the authors from 'Standard Industrial Classification' systems: SIC 1958 (for FES 1968), and SIC 1968 (for later surveys).

To operationalise equation (4) for Chart 3 and regression 2, we simplify variable $\mathrm{H}_{\mathrm{i}}$ to a dummy variable. It isn't clear what 'part-time' work means: "There is no specific number of hours that makes someone full or part-time" (Government Digital Service, 2013). We use the respondent's subjective assessment, from question 'In your (main) job were you working... (1) ... full time (2) or part time?" (ONS, 2013: 34).

\section{Results}

Chart 1 shows the evolution of weekly pay for UK men and women since 1968. It shows a steady improvement in average earnings of women (from about $24 \%$ of a man's earnings in 1968, to about $57 \%$ of male earnings in 2012); this convergence of women's and men's earnings may be due, at least partly, to the Equal Pay Act, 1970.

Chart 1. Average Earnings of Men and Women, By Year and Gender

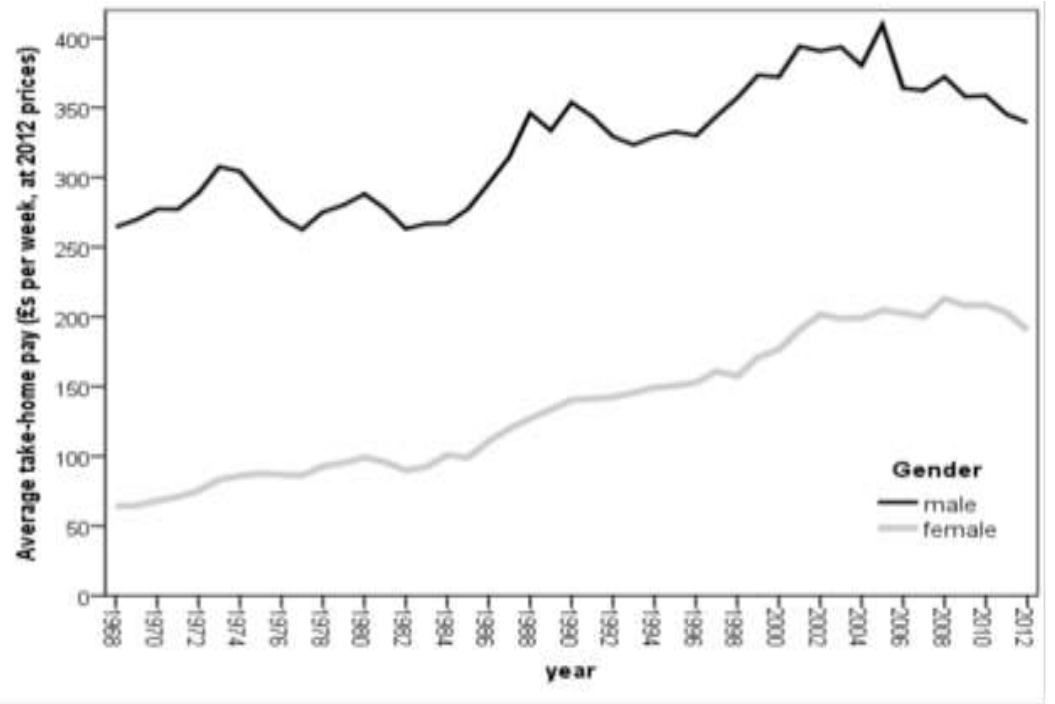

Source: FES (authors' analysis) 
Trends in Chart 1 may be due to many factors, such as more women taking full-time employment, or choosing not to take career breaks to have a family, or choosing to increase their human capital. Subsequent charts decompose the gender pay gap (in Chart 1) into four possible barriers to gender equality. Chart 2 explores the first 'barrier': the fraction of women in paid work. In previous decades, it was often assumed to be a woman's role to remain a 'housewife', or leave work to mind children, despite men being capable of housework (Scott \& Clery, 2013). Many women take time from their career to raise a family (maternity leave varies from a few months to several years), and may struggle to return to the wage they left the labour market at. It is now more acceptable in UK for men to share childcare (Scott \& Clery, 2013); some women delay having families, to pursue a career. Chart 2 suggests considerable convergence between genders from 1968 to 2012 - associated with fewer employed men, as well as more employed women. It is not clear from Chart 2 if lower male employment is a cause, or effect, of greater female employment: "Public support for a traditional division of gender roles within the home and the workplace has declined substantially over the last three decades, a change that goes hand in hand with the marked increase in the labour force participation of women and mothers. Changes in attitudes have been driven in part by generational replacement, indicating that we might expect a continuing decline of support for the traditional gender division of labour, in the future" (Scott \& Clery, 2013: 134). Regression analysis (appendix) shows a statistically significant difference in employment rates between men and women.

Chart 2. Fraction of Men and Women in Paid Work, By Year and Gender

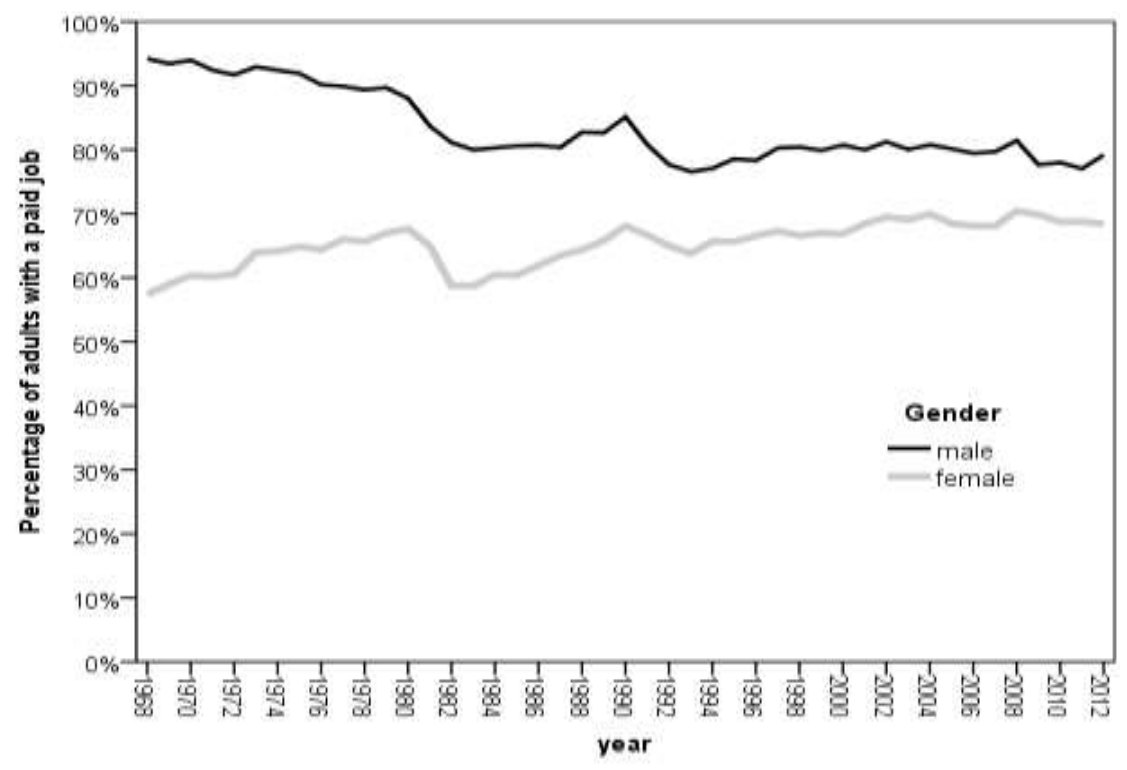

Source: FES (authors' analysis)

The second of four 'barriers' examined in this paper is number of paid hours per week, in Chart 3 (limited to men and women in paid employment), using the respondents' definition of "part-time". The authors' analysis of FES data indicate that this usually means under 31 hours per week. Bertrand, Kamenica \& Pan (2013) found some women who had the potential to earn more than their partner would work fewer hours, or leave their job: a woman may feel scared to earn more than her partner. Rationally, it appears better for the household and economy if such women stayed in work rather than their husband (except breast-feeding, but this is usually only for a few months - and may be limited to time of maternity leave). Booth \& van Ours (2010:4) report that among Dutch mothers of young children with part-time jobs, about $40 \%$ are part-time because they prefer part-time or have no choice but to provide childcare themselves. Chart 3 suggests a large gap between men and women, with little sign of convergence between genders from 1968 to 2012. This shows a different impression to Charts 1 and 2, where the gap between men and women seems to have narrowed since 1968. Many women may prefer part-time work; but perhaps some women have little choice. Booth \& van Ours (2010: 15) found Dutch men tend to prefer their wife/partner to be employed part-time. 
Chart 3. Fraction of Employees Who Say They Work Full-Time, By Year and Gender

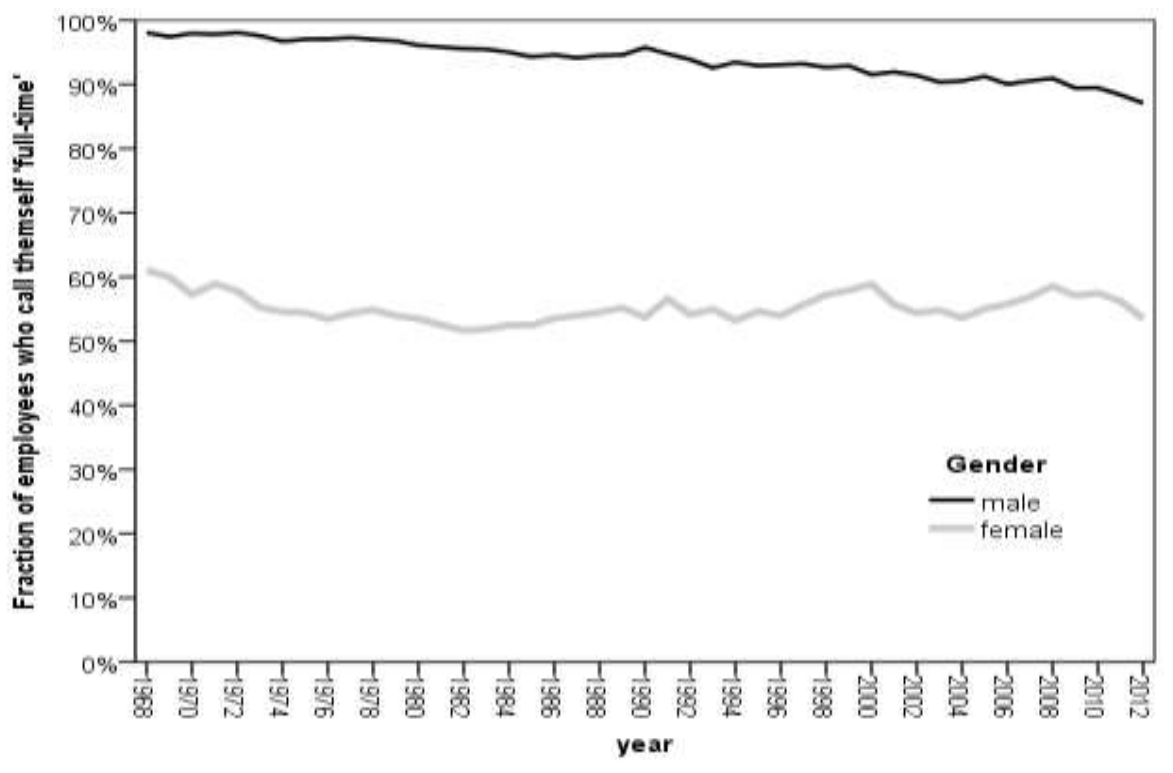

Source: FES (authors' analysis)

The third 'barrier' to gender equality examined in this paper is "glass ceilings", investigated in Chart 4. Promotion to managerial jobs is only one type of glass ceiling - there are many ways in which women are excluded from well-paid jobs: for example, if universities refuse to accept female students on physics degrees, some occupations may be unavailable to women. Becker (1971) suggests some employers may be hostile to women.

Chart 4. Fraction of People In Managerial Jobs Who are Women, By Year

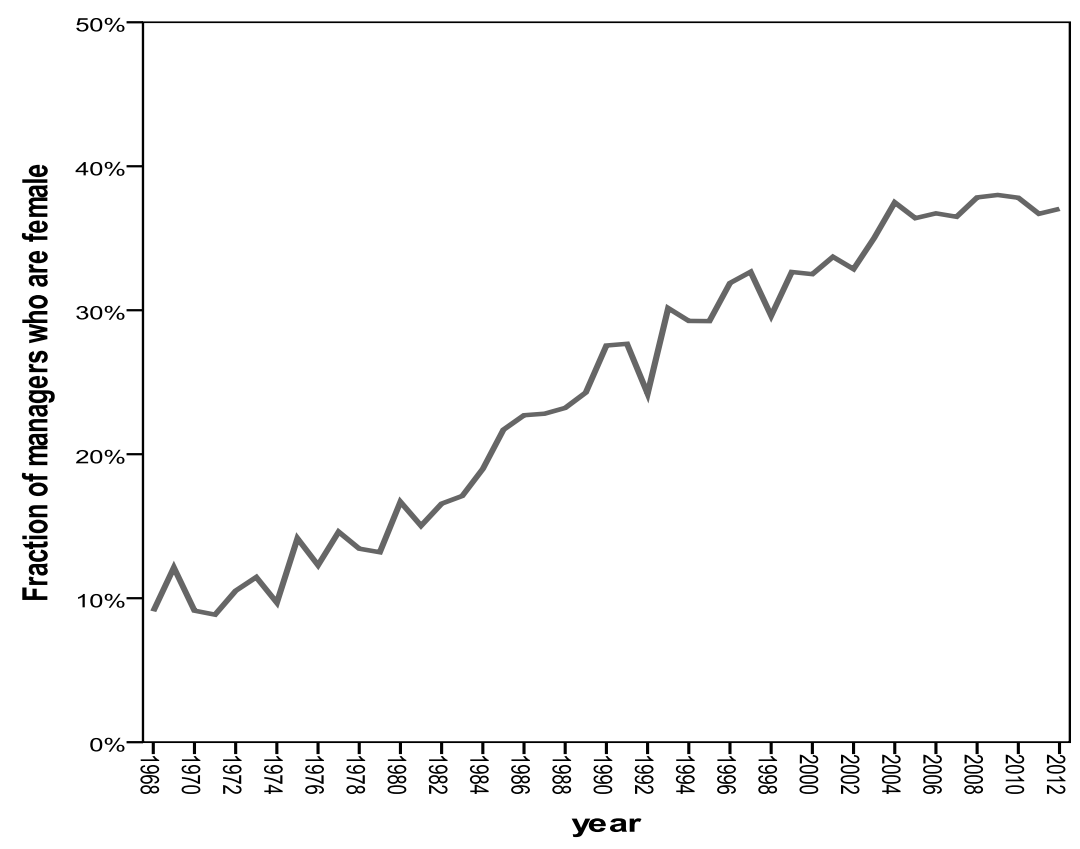

Source: FES (authors' analysis)

Chart 4 suggests decreasing gender inequality in UK from 1968 to 2012. This trend may be related to the Sex Discrimination Act, which created equal opportunities for women \& men in workplaces - women became entitled to the same opportunities in terms of promotions and training for higher roles, where previously they may have been overlooked; women now have better access to higher managerial roles. An alternative explanation for the upward trend in Chart 4 is adult socialisation: role models such as Margaret Thatcher may have influenced women directly or 
indirectly, through attitudes to women's roles - perhaps encouraging women to choose university courses with high earnings potential, and leading more women to apply for promotion. Another possibility is changing child socialisation: young adults in 2012 may have become used to women in positions of power.

Chart 5. Women'S Pay Relative to Men: Full-Time Managers

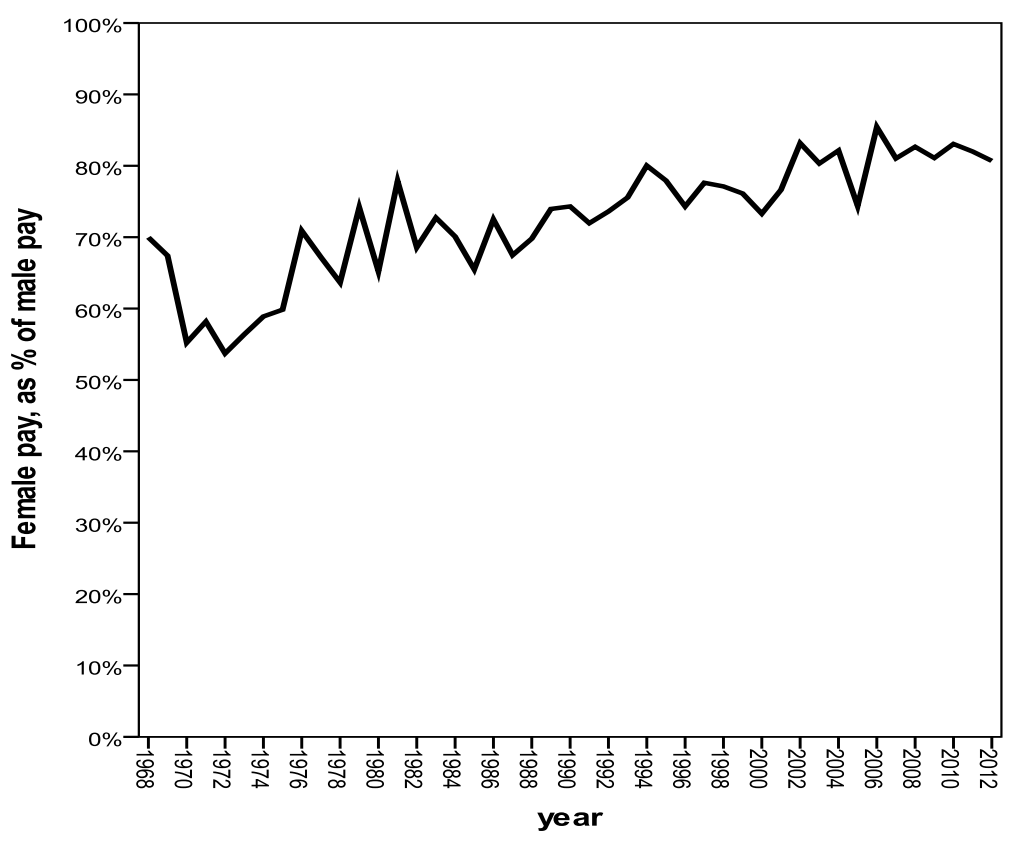

Source: FES (authors' analysis)

Chart 5 reports equality of pay among full-time managers, to limit the possibility that apparent gender wages differences are influenced by skill level or part-time work. Chart 5 shows a slight overall increase in the average female manager's wage, as a percentage of the average male manager's wage. This could be considered the most direct measurement of wage discrimination. There was a noticeable increase in relative pay from 1975 to 1976 ; this may be a result of the Equal Pay Act 1970 (which came into force from 1975), or the Sex Discrimination Act 1975.

Chart 6. Fraction of the Workforce who are Female, By Industry and Year

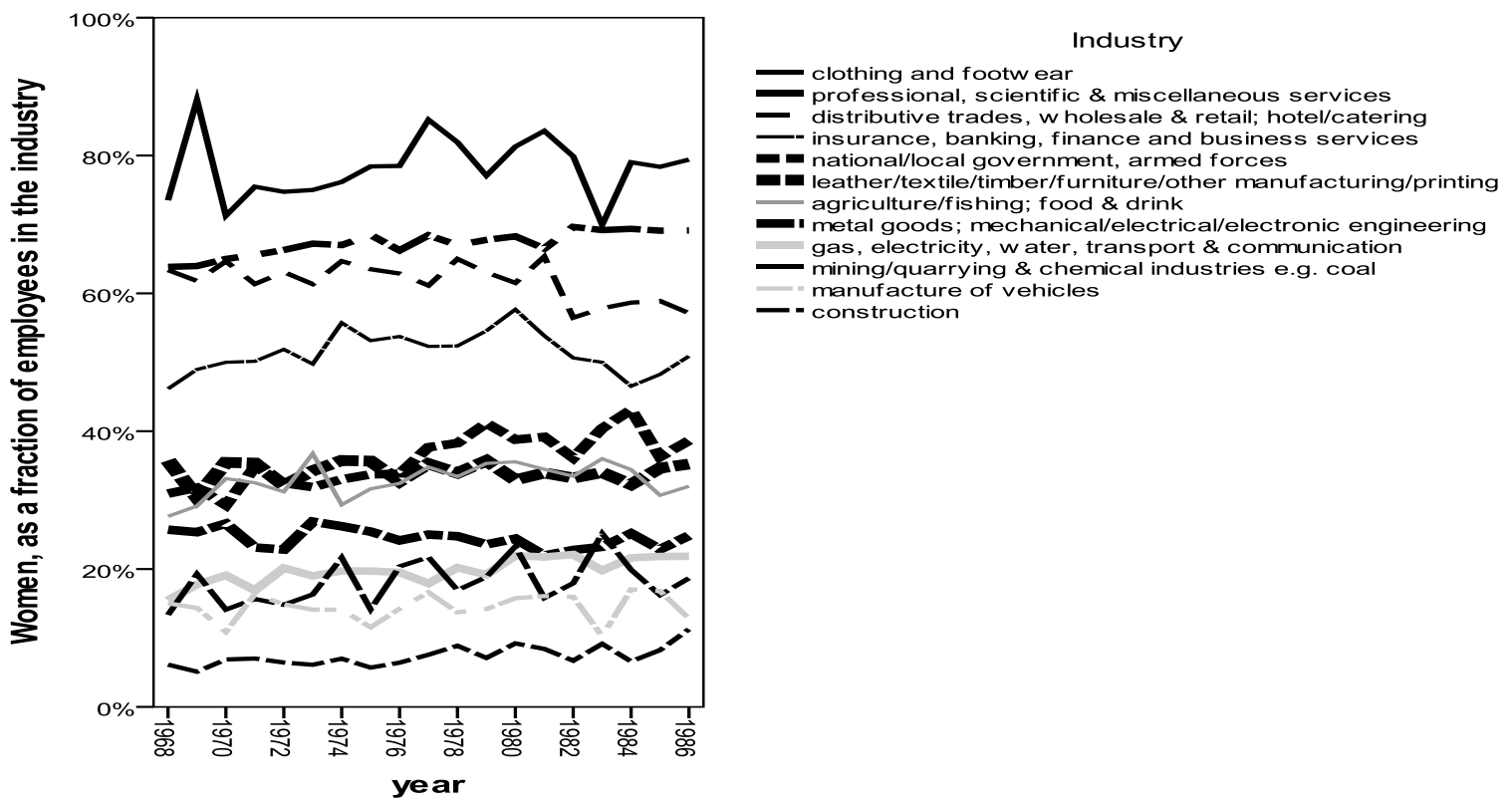

Source: FES (authors' analysis) 
Increased female employment in industries that were previously male-dominated could lead to better access to high-earning occupations such as engineering. Hence, women's increasing pay (relative to men) in Chart 1 in this paper might be explained by women moving into jobs previously done by men; but Chart 6 suggests otherwise. Chart 6 shows changes in the gender mix in recent decades, by industry; industry codes were simplified by the authors, combining 'Standard Industrial Classification' systems SIC 1958 and SIC 1968. There is no obvious convergence from 1968 to 1986. FES surveys are unhelpful after 1986, regarding the industry in which respondents worked.

Various factors contribute to women earning higher wages (relative to men) since 1968, as shown in Chart 1 . Some factors affecting pay-rates, such as region variation within the UK, are investigated in the appendix: regression analysis indicates the gender pay gap is statistically significant. Charts 2 to 6 offer insights into what aspects of the labour market changed in recent decades; women's access to paid work, and especially full-time work, seemed resistant to change (Charts 2 and 3). The industries where women tend to work also shows little tendency to change (Chart 6). There has been some tendency for pay of female managers to catch up with pay of male managers (Chart 5); many more women now enter managerial jobs (Chart 4).

If gender pay gaps exist, we should not put all the blame on employers. If we can imagine a country in which the demand for labour was unprejudiced, we might still find fewer women than men employed, because of personal or household choices (many men might refuse to perform an equal share of domestic tasks such as childcare). If a previous generation of children were socialised such that girls were encouraged to play with dolls and boys encouraged to play with cars, it could cause many women to prefer to remain a 'housewife', with few men choosing to be a 'househusband'. Male-dominated trade unions might support equal pay because they believe managers would hire more women, if female wages were lower than men (equal pay may lead to fewer women being hired, reducing male unemployment, if discrimination exists). Schools and universities could help break down barriers, by making it easier for women to enter degrees such as physics and engineering which are male-dominated. Woolley (1998: 310) claims feminist economists should seek three aims: to document differences in the well-being of men \& women; advocate policies which promote equality; and conduct unbiased research. Bergmann (cited in Woolley, 1998: 309) wrote "what really distinguishes feminist economists is their view that the present assignment of economic duties based on sex is unfair and should be eliminated".

\section{Conclusions}

This paper investigates four possible explanations of earning differences between men \& women: whether a person is employed; the number of hours they work per week; if they do managerial or non-managerial work; and their wage-rate. Gender discrimination may reduce a woman's ability to find any employment; trap her in part-time work; keep her in a low-paid job; or give her a lower wage-rate than men.

Evidence in this paper show improvements since 1968: this paper reports evidence of progress towards symmetry between genders. Chart 5 shows an increase in female relative wages - confirmed by regression analysis. But there are persistent barriers to gender equality in UK, such as part-time work. Gender differences in employment have many causes, including labour supply: some women choose to remain a 'housewife', or take a part-time job, to raise children. Booth \& van Ours (2010: 16), studying the Netherlands, found "the evidence leads us to conclude that the current situation with most women working in part-time jobs is unlikely to be a transitional phenomenon. Partnered female part-time labor in the Netherlands is here to stay". Chart 3 in this paper suggests a similar pattern in the UK; and Chart 6 indicates a tendency for some types of job to be mainly carried out by one gender.

From evidence in this paper, the UK labour force has not provided the gender equality which neoclassical economics predicts. Efficiency and equity arguments both suggest that meritocracy is appropriate; policy-makers should consider various ways to reduce unfairness. Gender inequality in the labour market is an amalgamation of various social pre- and post-market attitudes, employers' discrimination, and flawed legislation \& economic policy. Ideas about what professions women should pursue are imprinted during childhood socialisation, and reinforced by media and social norms. Non-labour-market discrimination creates asymmetry: disparities between genders are increased in labour markets. Productivity may account for some of pay differentials (such as fewer women than men having science degrees), but gender discrimination and female disadvantage exist - shown by regression analysis in this paper, and in previous research. Horizontal \& vertical occupational segregation in the labour market, and wage discrimination, are unfair to women. Progress towards equality is slow; policies and legislation have limited effectiveness - changes in attitudes are also required. Equal pay for woman would reduce labour market distortions, and encourage optimal choices (for example, if a woman is more educated than her husband, it may be appropriate for her to be the main earner while her husband minds their children). Unfairness to women prevents the UK from achieving its potential maximum efficiency and equity. 


\section{Bibliography}

Alesina, A., \& Giuliano, P. (2010). Fertility and the Plough. NBER Working paper 16719(1). http://dx.doi.org/10.1109/2.901164

Anker, R. (1998). Gender and jobs: sex segregation of occupation in the world. Work, Employment, and Society. 14(2), 401-16. http://dx.doi.org/10.1111/j.1468-0432.2007.00362_2.x

Bandiera, O. \& Natraj, A. (2013). Does gender inequality hinder development and economic growth? Evidence and policy implications. World Bank Research Observer. 28(1), 2-12. http://dx.doi.org/10.1596/1813-9450-6369

Becker, G. (1971). The economics of discrimination. $2^{\text {nd }}$ edition, London: University of Chicago press. http://dx.doi.org/10.7208/chicago/9780226041049.001.0001

Bertrand, M., Kamenica, E., \& Pan, J. (2013). Gender Identity and Relative Income within Households. Chicago Booth Research Paper 13-08 (2013). http://dx.doi.org/10.3386/w19023

Blau, F. \& Simpson, P. (1998). Continuing Progress? Trends in occupational segregation in the United States over the 1970s and 1980s. Feminist economics. 4(3), 29-71. http://dx.doi.org/10.3386/w6716

Booth, A. L., \& van Ours, J. C. (2010). Part-Time Jobs: What Women Want? Discussion Paper 4686, Forschungsinstitutzur Zukunft der Arbeit: Bonn. http://ftp.iza.org/dp4686.pdf accessed 31 ${ }^{\text {st }}$ August 2014.

Branisa, B., Klasen, S., Ziegler, M., Drechsler, D. \& Jütting, J. (2013). The institutional basis of gender inequality: The Social Institutions and Gender Index (SIGI). Feminist economics. 20(2), 29-64.

Chiplin, B., \& Sloane, P. (1974). Sexual discrimination in the labour market. British Journal of Industrial Relations. 12(3), 371-402.

Clarke, L. (1994). Discrimination. London: Institute of personnel management. ISBN: 085292528X.

Corbett, C., \& Hill, C. (2012). Graduating to a pay gap: The earnings of women and men one year after college graduation. AAUW. http://www.aauw.org/research/graduating-to-a-pay-gap/ accessed $27^{\text {th }}$ May 2014.

Ehrenberg, R., \& Smith, R. (2000). Modern labour market economics: Theory and policy. $7^{\text {th }}$ ed. Harlow: Addison-Wesley.

England, P. (1982). The failure of human capital theory to explain occupational sex segregation. Journal of human resources. 17(3), 358-70. http://dx.doi.org/10.2307/145585

Government Digital Service (2013). Part-time worker's rights. https://www.gov.uk/part-time-worker-rights accessed $18^{\text {th }}$ February 2014.

Gunderson, M. (2006). Viewpoint: male-female wage differentials: how can that be? Canadian Journal of Economics, $39(1), 1-21$.

Guy, M \& Newman, N. (2004). Women's jobs, men's jobs: sex segregation and emotional labour. Public Administration review. 64(3), http://dx.doi.org/10.1111/j.1540-6210.2004.00373.x

Harkness, S. (1996). The gender earnings gap: evidence from the UK. Fiscal Studies. 17(2), 1-36. http://dx.doi.org/10.1111/j.1475-5890.1996.tb00241.x

Hausmann, R. (2012). The global gender gap report. Insight report, World economic forum. (1), 1-30. http://dx.doi.org/10.4135/9781452270388.n478

Hirsch, B., König, M. \& Möller, J. (2013). Is there a gap in the Gap? Regional differences in the gender pay gap. Scottish Journal of Political Economy 60(4), 412-39.

Jann, B. (2008). The Blinder-Oaxaca decomposition for linear regression models. Stata Journal 8(4), 453-79. www.stata-journal.com/article.html?article=st0151 accessed $28^{\text {th }}$ May 2014.

McNabb, R. \& Ryan, P. (1990). Segmented labour markets. Current issues in labour economics. 1(1), 4.

Mincer, J. \& Polacheck, S. (1974). Family investments in human capital: earnings of women. Marriage, Family, Human Capital, and Fertility. 1(1), 76-110. http://dx.doi.org/10.1086/260293

ONS (2013). Living Costs and Food Survey, volume B: the household questionnaire user guide, January-December 2012, Office for National Statistics: London.

Pahl, J. (1990). Household Spending, Personal Spending and the Control of Money in Marriage. Sociology. 24(1), 119-38. http://dx.doi.org/10.1177/0038038590024001009

Patterson, M. (1997). Impact of people management practices on business performance. Issues in people management. $1(1)$. 
Pomerantz, D. (2012), Gordon Ramsay tops our list of the highest earning chefs, Forbes. www.forbes.com/sites/dorothypomerantz/2012/07/18/gordon-ramsay-tops-our-list-of-the-highest-earning-chefs/ accessed $28^{\text {th }}$ May 2014.

Samuelson, P. A. \& Nordhaus, W. D. (2005). Economics. McGraw-Hill: Singapore.

Scott, J. \& Clery, E. (2013). Gender roles: an incomplete revolution? pp. 115-38 in Park, A., Bryson, C., Clery, E., Curtice, J. \& Phillips, M. (eds.), British Social Attitudes: the 30 ${ }^{\text {th }}$ Report, London: NatCen Social Research: www.bsa-30.natcen.ac.uk Accessed $28^{\text {th }}$ May 2014.

Seguino, S. (2000). Gender inequality and economic growth: a cross-country analysis. World Development. 28(7), 1211-230. http://dx.doi.org/10.1016/s0305-750x(00)00018-8

Townshend, R. (1989). Sex discrimination in employment: law, practice, and policy. London: Sweet and Maxwell.

UK government (2010). The gender pay gap in the UK: 1995 to 2007. Government equalities office: research findings 2010/2. www.equalities.gov.uk/pdf/GPAYGAP_gpg_summary_FINAL.pdf accessed 10 ${ }^{\text {th }}$ September 2013.

UK government (2013). Long term indicator of prices of consumer goods and services. www.ons.gov.uk/ons/rel/cpi/consumer-price-indices/july-2013/cpi-time-series-data.html accessed $8^{\text {th }}$ September 2013.

Vinnicomb, S \& Doldor, E (2014). The female FTSE board report 2014. The Cranfield Report. Cranfield University.

Woolley, F. R. (1998). The feminist challenge to neoclassical economics, in Prychitko D. L. (ed.), Why economists disagree, SUNY Press, Albany.

\section{Appendix: Regression Results}

There are four regression equations, one for each 'barrier'. Logistic regression is used for the first three barriers, with a dummy (zero or one) dependent variable; the fourth uses OLS regression. In all four regressions, the dummy variables for year (1968 to 1986) apply to women in the sample, treating men in 1968 as the reference category. The reference region is South-East England; reference age-group is under 20; reference quarter is quarter 1; reference job is professional/technical; and reference industry is professional/scientific/miscellaneous services. SIC is a simplified version of 'Standard Industrial Classification', produced by the authors, as in Chart 6. Data after 1986 are excluded from each regression, because industry is not reported after 1986. Region, industry, and age are control variables, to distinguish effects of gender from other possible influences on productivity - using a method similar to the 'Blinder-Oaxaca decomposition' discussed in this paper.

The first regression tests 'barrier one': whether women are as likely as men to be employed. The dependent variable is zero (not employed) or one (employed); the negative coefficient (-1.961) indicates women are less likely to be employed than men (gender is negative and statistically significant for all four regressions). Lower rows compare 1969 to 1986 with reference year 1968: they are positive, indicating women catching up with men (see Chart 2). The largest coefficients are for 1975 to 1981, perhaps showing effects of the Equal Pay Act 1970 or Sex Discrimination Act 1975.

The second regression uses full-time (coded one) or part-time (coded zero) as the dependent variable. Women are less likely than men to be full-time (-2.033); negative coefficients show this gap increasing, consistent with Chart 3.

The next regression tests the third barrier, "glass ceilings". The dependent variable is 1 if an employee is a manager, or zero for other employees in the second column (professional/technical, to unskilled). Positive coefficients for 1969 to 1986 show increasing female access to managerial jobs since 1968 (Chart 4 confirms this long-term trend).

The final regression uses OLS regression with Log of wage as the dependent variable, for all employees. Positive coefficients from 1969 to 1986 show women catching up with male wages. Chart 5 is limited to full-time managers, to test the fourth barrier; the fourth regression includes all occupations, and part-time as well as full-time employees, but includes variables to identify effects of the second, third, and fourth barriers.

Table 1. Regression Results

\begin{tabular}{lllllllllll}
\hline Group & Category & regression 1 & regression 2 & regression 3 & regression 4 \\
\hline & Gender & -1.961 & $* *$ & -2.033 & $* *$ & -2.171 & $* *$ & -.223 & $* *$ \\
& 1969 & .106 & $* *$ & -.067 & & .543 & $*$ & .006 & \\
& 1970 & .131 & $* *$ & -.227 & $* *$ & .427 & & .016 & $* *$ \\
\multirow{6}{*}{ Year } & 1971 & .122 & $* *$ & -.139 & $*$ & .221 & & .026 & $* *$ \\
& 1972 & .145 & $* *$ & -.276 & $* *$ & .612 & $* *$ & .048 & $* *$ \\
& 1973 & .296 & $* *$ & -.317 & $* *$ & .578 & $* *$ & .074 & $* *$ \\
\hline
\end{tabular}




\begin{tabular}{|c|c|c|c|c|c|c|c|c|c|}
\hline & 1974 & .313 & $* *$ & -.388 & $* *$ & .638 & $* *$ & .079 & $* *$ \\
\hline & 1975 & .348 & $* *$ & -.369 & $* *$ & .891 & $* *$ & .082 & $* *$ \\
\hline & 1976 & .332 & $* *$ & -.370 & $* *$ & .849 & $* *$ & .089 & $* *$ \\
\hline & 1977 & .406 & $* *$ & -.299 & $* *$ & 1.057 & $* *$ & .070 & $* *$ \\
\hline & 1978 & .384 & $* *$ & -.289 & $* *$ & 1.027 & $* *$ & .099 & $* *$ \\
\hline & 1979 & .440 & $* *$ & -.348 & $* *$ & 1.005 & $* *$ & .100 & $* *$ \\
\hline & 1980 & .470 & $* *$ & -.339 & ** & 1.248 & ** & .102 & $* *$ \\
\hline & 1981 & .357 & $* *$ & -.341 & $* *$ & 1.079 & $* *$ & .105 & $* *$ \\
\hline & 1982 & .102 & $* *$ & -.387 & $* *$ & 1.217 & $* *$ & .099 & $* *$ \\
\hline & 1983 & .084 & $*$ & -.427 & $* *$ & 1.282 & $* *$ & .111 & $* *$ \\
\hline & 1984 & .163 & $* *$ & -.346 & ** & 1.288 & ** & .124 & $* *$ \\
\hline & 1985 & .153 & $* *$ & -.420 & $* *$ & 1.585 & $* *$ & .130 & $* *$ \\
\hline & 1986 & .212 & $* *$ & -.396 & $* *$ & 1.523 & $* *$ & .147 & $* *$ \\
\hline & N. England & -.451 & $* *$ & .078 & $*$ & -.755 & $* *$ & -.034 & $* *$ \\
\hline & Yorkshire/Humberside & -.294 & $* *$ & -.028 & & -.553 & $* *$ & -.032 & $* *$ \\
\hline & E. Midlands & -.117 & $* *$ & -.084 & * & -.407 & $* *$ & -.034 & ** \\
\hline & E. Anglia & -.154 & $* *$ & .078 & & -.526 & $* *$ & -.029 & $* *$ \\
\hline & Greater London & .042 & & .171 & ** & -.091 & * & .030 & $* *$ \\
\hline Region & S. West England & -.167 & $* *$ & .050 & & -.462 & $* *$ & -.031 & $* *$ \\
\hline & Wales & -.556 & $* *$ & .138 & $* *$ & -.677 & ** & -.031 & $* *$ \\
\hline & W. Midlands & -.204 & $* *$ & .001 & & -.378 & ** & -.026 & $* *$ \\
\hline & N. West England & -.261 & $* *$ & .075 & $* *$ & -.432 & $* *$ & -.024 & $* *$ \\
\hline & Scotland & -.376 & $* *$ & .245 & $* *$ & -.629 & $* *$ & -.028 & $* *$ \\
\hline & N. Ireland & -.771 & $* *$ & .563 & $* *$ & -1.176 & $* *$ & -.047 & $* *$ \\
\hline & 20 to 29 years & -.398 & ** & .006 & & 1.692 & ** & .164 & $* *$ \\
\hline & 30 to 39 years & -.300 & $* *$ & -.841 & ** & 2.481 & ** & .215 & $* *$ \\
\hline & 40 to 49 years & -.043 & & -.691 & ** & 2.552 & ** & .210 & $* *$ \\
\hline & 50 to 59 years & -.537 & $* *$ & -.507 & $* *$ & 2.460 & $* *$ & .191 & $* *$ \\
\hline & Quarter 2 & -.003 & & .067 & $* *$ & -.004 & & .011 & $* *$ \\
\hline Qtr & Quarter 3 & .001 & & .095 & $* *$ & .027 & & .024 & $* *$ \\
\hline & Quarter 4 & .000 & & .063 & $* *$ & .002 & & .037 & $* *$ \\
\hline & admin/managerial & & & .544 & $* *$ & & & .135 & $* *$ \\
\hline & Teacher & & & 1.263 & $* *$ & & & .139 & $* *$ \\
\hline & clerical worker & & & -1.127 & ** & & & .262 & $* *$ \\
\hline Job & shop assistant & & & .170 & ** & & & .030 & $* *$ \\
\hline & manual: skilled & & & -.784 & $* *$ & & & -.050 & $* *$ \\
\hline & manual: semi-skilled & & & -.706 & ** & & & -.040 & $* *$ \\
\hline & manual: unskilled & & & -1.539 & ** & & & -.076 & $* *$ \\
\hline & agriculture/fishing; food \& drink & & & 1.034 & $* *$ & -.371 & $* *$ & .026 & $* *$ \\
\hline SIC & mining/quarrying \& chemical industries & & & 1.193 & ** & -.643 & ** & .108 & $* *$ \\
\hline & metal goods; mech/electric/electronic engineering & & & 1.235 & $* *$ & -.519 & $* *$ & .065 & $* *$ \\
\hline & Manufacture of vehicles & & & 1.118 & ** & -1.097 & ** & .088 & ** \\
\hline
\end{tabular}




\begin{tabular}{|c|c|c|c|c|c|c|c|}
\hline Clothing and footwear & & 1.315 & $* *$ & -.238 & * & .030 & $* *$ \\
\hline leather/textile/timber/furniture/other manuf/print & & 1.110 & $* *$ & -.416 & $* *$ & .060 & $* *$ \\
\hline Construction & & .932 & $* *$ & -.646 & $* *$ & .052 & $* *$ \\
\hline gas, electricity, water, transport/communication & & 1.384 & $* *$ & -.739 & $* *$ & .061 & $* *$ \\
\hline Distributive trades; hotel/catering & & .232 & $* *$ & .830 & $* *$ & -.002 & \\
\hline Insurance, banking, finance, business services & & .582 & $* *$ & .932 & $* *$ & .083 & $* *$ \\
\hline national/local government, armed forces & & 1.401 & $* *$ & .415 & $* *$ & .071 & $* *$ \\
\hline Full-time & & & $* *$ & 1.671 & $* *$ & -.080 & $* *$ \\
\hline Constant & $2.809 * *$ & 2.454 & $* *$ & -5.227 & $* *$ & .617 & $* *$ \\
\hline Sample size & 200,678 & 144,3 & & 124,15 & & 144 & \\
\hline Pseudo- $R^{2}$ or $R^{2}$ & 0.17 & 0.46 & & 0.20 & & 0.4 & \\
\hline
\end{tabular}

Source: FES data, 1968-1986 (authors' analysis). ** indicates statistically significant at 1\%; * shows 5\% significance.

\section{(c) EY}

This work is licensed under a Creative Commons Attribution 3.0 License. 